\title{
Improving High-Latitude Rice Nitrogen Management with the CERES-Rice Crop Model
}

\author{
Jing Zhang ${ }^{1}$, Yuxin Miao ${ }^{1,2, *} \mathbb{0}$, William D. Batchelor ${ }^{3}$, Junjun Lu ${ }^{1,4}$, Hongye Wang ${ }^{1}$ and \\ Shujiang Kang ${ }^{2}$ \\ 1 Center for Resource, Environment and Food Security, College of Resources and Environmental Sciences, \\ China Agricultural University, Beijing 100193, China; jingz9468@gmail.com (J.Z.); \\ junjunlu@hpu.edu.cn (J.L.); wanghongye656@gmail.com (H.W.) \\ 2 Precision Agriculture Center, Department of Soil, Water and Climate, University of Minnesota, \\ St. Paul, MN 55108, USA; skang2010apr@gmail.com \\ 3 Biosystems Engineering Department, Auburn University, Auburn, AL 36849, USA; wdb0007@auburn.edu \\ 4 School of Surveying and Land Information Engineering, Henan Polytechnic University, \\ Jiaozuo 454000, China \\ * Correspondence: ymiao@cau.edu.cn or ymiao@umn.edu; Tel.: +86-138-1104-8358
}

Received: 8 October 2018; Accepted: 11 November 2018; Published: 15 November 2018

\begin{abstract}
Efficient use of nitrogen (N) fertilizer is critically important for China's food security and sustainable development. Crop models have been widely used to analyze yield variability, assist in $\mathrm{N}$ prescriptions, and determine optimum $\mathrm{N}$ rates. The objectives of this study were to use the CERES-Rice model to simulate the $\mathrm{N}$ response of different high-latitude, adapted flooded rice varieties to different types of weather seasons, and to explore different optimum rice $\mathrm{N}$ management strategies with the combinations of rice varieties and types of weather seasons. Field experiments conducted for five $\mathrm{N}$ rates and three varieties in Northeast China during 2011-2016 were used to calibrate and evaluate the CERES-Rice model. Historical weather data (1960-2014) were classified into three weather types (cool/normal/warm) based on cumulative growing degree days during the normal growing season for rice. After calibrating the CERES-Rice model for three varieties and five $\mathrm{N}$ rates, the model gave good simulations for evaluation seasons for top weight $\left(R^{2} \geq 0.96\right)$, leaf area index $\left(R^{2} \geq 0.64\right)$, yield $\left(R^{2} \geq 0.71\right)$, and plant $\mathrm{N}$ uptake $\left(R^{2} \geq 0.83\right)$. The simulated optimum $\mathrm{N}$ rates for the combinations of varieties and weather types ranged from 91 to $119 \mathrm{~kg} \mathrm{~N}^{-1}$ over 55 seasons of weather data and were in agreement with the reported values of the region. Five different $\mathrm{N}$ management strategies were evaluated based on farmer practice, regional optimum $\mathrm{N}$ rates, and optimum $\mathrm{N}$ rates simulated for different combinations of varieties and weather season types over 20 seasons of weather data. The simulated optimum $\mathrm{N}$ rate, marginal net return, and $\mathrm{N}$ partial factor productivity were sensitive to both variety and type of weather year. Based on the simulations, climate warming would favor the selection of the 12-leaf variety, Longjing 21, which would produce higher yield and marginal returns than the 11-leaf varieties under all the management strategies evaluated. The 12-leaf variety with a longer growing season and higher yield potential would require higher $\mathrm{N}$ rates than the 11-leaf varieties. In summary, under warm weather conditions, all the rice varieties would produce higher yield, and thus require higher rates of $\mathrm{N}$ fertilizers. Based on simulation results using the past 20 years of weather data, variety-specific $\mathrm{N}$ management was a practical strategy to improve $\mathrm{N}$ management and $\mathrm{N}$ partial factor productivity compared with farmer practice and regional optimum $\mathrm{N}$ management in the study region. The CERES-Rice crop growth model can be a useful tool to help farmers select suitable precision $\mathrm{N}$ management strategies to improve $\mathrm{N}$-use efficiency and economic returns.
\end{abstract}


Keywords: crop model; high latitude rice; nitrogen use efficiency; precision nitrogen management; sustainable development; variety-specific management; weather-specific management

\section{Introduction}

Rice (Oryza sativa L.) is an important staple cereal crop that is sustenance to over half of the world's population [1]. China produces $28 \%$ of global rice production, but consumes $36 \%$ of the global nitrogen $(\mathrm{N})$ used for rice production [2]. While rice farm size in China is typically less than one ha, rice farm size in the Sanjiang Plain of Northeast China is around 20 ha, representing a large-scale farming system in China. Northeast China has a cool climate, but rice production in this region is vital for the nation's food security [3,4]. Most farmers apply $\mathrm{N}$ fertilizers based on their experience, but this has led to common problems, such as over-application, improper timing, low N-use efficiency (NUE), and environmental $\mathrm{N}$ losses [4-6]. New approaches to develop $\mathrm{N}$ management strategies are urgently needed to improve NUE and reduce $\mathrm{N}$ loss to the environment.

The current priority for China to improve $\mathrm{N}$ management is to develop regional optimum $\mathrm{N}$ rates (RONR) at the scales of provinces, counties, or townships to avoid significant over- or under-application of $\mathrm{N}$ fertilizers [7]. It has been found that RONRs for rice ranged from 114 to $224 \mathrm{~kg} \mathrm{ha}^{-1}$ in China, with an average of $167 \mathrm{~kg} \mathrm{ha}^{-1}$ [8]. If this RONR approach were adopted in China, $\mathrm{N}$ fertilizer applications would be decreased in $56 \%$ of fields and increased in $33 \%$ of fields. This would result in a $7 \%$ increase in rice yield and an $11 \%$ reduction in greenhouse gas emissions [8]. This approach is simple to implement, and does not require soil and plant testing, thus making it a good starting point to bring farmer $\mathrm{N}$ application rates to a relatively optimal range [9]. However, it should be realized that with the RONR strategy, $\mathrm{N}$ fertilizers are applied at a fixed timing and rate and does not consider differences in soil fertility, varieties, and weather conditions, which can significantly influence optimum $\mathrm{N}$ rates [10-12].

Remote and proximal sensing technologies are commonly used to diagnose crop $\mathrm{N}$ status and determine in-season $\mathrm{N}$ application rates [13-15]. In addition, crop simulation models and their associated decision support systems have been demonstrated in many countries around the world for a wide range of applications, including determining site-specific and variety-specific optimal $\mathrm{N}$ application rates and making $\mathrm{N}$ recommendations [11,16-18]. Crop models can extend the results of limited field experiments to other soil types and weather conditions.

The DSSAT (Decision Support System for Agrotechnology Transfer) family of crop growth models is widely used around the world [11,16,19-23]. The CERES-Rice model included in DSSAT is physiologically based and simulates daily canopy photosynthesis, respiration, growth, biomass partitioning, and development as a function of input information, including daily weather conditions, soil properties, management practices, and variety characteristics. The model has primarily been evaluated in warm climates for different crop management practices [24-27]. It has also been used to evaluate the impact of various planting densities and $\mathrm{N}$ application rates on rice yield and economic returns under irrigation [28] and to simulate the impacts of climate change on rice production [29].

However, the CERES-Rice model has not been evaluated for rice grown under high-latitude cool climate conditions like Northeast China. Therefore, the specific objectives of this study were to: (1) calibrate and evaluate the CERES-Rice model using $\mathrm{N}$ rate experiments with three rice varieties conducted in the Sanjiang Plain, China; (2) use the model to evaluate the long-term economic optimum $\mathrm{N}$ rates for different varieties and weather types (cool, normal, and warm); and (3) evaluate the potential benefits of variety-specific and weather-specific $\mathrm{N}$ management strategies, as compared to the RONR approach in Northeast China. 


\section{Materials and Methods}

\subsection{Study Site Description}

The study site at Jiansanjiang, located in the Sanjiang Plain, Heilongjiang province, is the leading large-scale rice farming system in China. It has a temperate continental monsoon climate with cold winters and warm summers, with an annual average temperature of about $1-2{ }^{\circ} \mathrm{C}$, annual rainfall between 500 and $600 \mathrm{~mm}$, and annual frost-free period of 120 to 140 days [30]. The area consists of typical alluvial soil formed by the Songhua River, Heilong River, and Wusuli River. The soil is classified as Mollisol with an Albic horizon, wet black clay approximately $20 \mathrm{~cm}$ thick, and high organic matter content $(>4 \%)$ [31]. The region was reclaimed from wetlands approximately $60-70$ years ago, and has been used primarily for paddy rice production.

\subsection{Field Management}

Two field experiments with five $\mathrm{N}$ rates were conducted during 2011-2016 at the Jiansanjiang Experiment Station of China Agricultural University. The two experiments consisted of five $\mathrm{N}$ rate treatments, including 0, 70, 100, 130, and $160 \mathrm{~kg} \mathrm{~N} \mathrm{ha}^{-1}$ from 2011 to 2013, and 0, 40, 80, 120, and $160 \mathrm{~kg}$ $\mathrm{N} \mathrm{ha}^{-1}$ from 2014 to 2016. The varieties Kongyu 131 and Longjing 21 were planted from 2011 to 2013, and Longjing 31 and Longjing 21 were planted from 2014 to 2016. Both Kongyu 131 and Longjing 31 are 11-leaf varieties, and Longjing 21 is a 12-leaf variety. A randomized complete block design with three replicates was used for these experiments. The total $\mathrm{N}$ (urea as source) was split into three applications, with $40 \%, 30 \%$, and $30 \%$ being applied before transplanting, at the tillering stage and stem elongation stage, respectively. All other field management practices, including irrigation, planting, and pest management, followed the local recommended practices. Weather data, including the daily maximum and minimum temperature, rainfall, and sunshine hours were collected from the local weather station.

\subsection{Plant Sampling and Measurements}

Rice plant biomass samples were collected at the panicle initiation, stem elongation, and heading stages. The average tiller number for each plot was measured at the tillering stage. Leaf area index (LAI) was calculated using the dry weight method [32]. Plant samples were separated into leaves, stems, and panicles, and dried in an oven at $105^{\circ} \mathrm{C}$ for 30 minutes to deactivate enzymes. Next, the samples were dried at $75{ }^{\circ} \mathrm{C}$ until constant weight, and then biomass was weighed. Total aboveground biomass was determined and total $\mathrm{N}$ concentration was analyzed using the Kjeldahl-N method. Plant $\mathrm{N}$ uptake was calculated by multiplying the total aboveground biomass with plant $\mathrm{N}$ concentration. At maturity, three $1-\mathrm{m}^{2}$ areas were randomly selected for grain yield measurement in each plot.

\subsection{Model Calibration and Evaluation}

Experimental data for Longjing 21 during 2015 and 2016, Longjing 31 during 2016, and Kongyu 131 during 2012 and 2013 were selected for the calibration of CERES-Rice. Nine cultivar coefficients (Table 1) were estimated to calibrate the model for each variety and $\mathrm{N}$ rate treatment. The CERES-Rice model calibration involved making systematic adjustments to the development and growth cultivar coefficients to minimize error between simulated and measured total aboveground biomass, LAI, and yield. The coefficients P1, P2O, and P2R were adjusted so that the model simulated the correct timing of top weight and LAI, which were measured at different key growth stages during the growing season. The coefficient PHINT was adjusted to give the best fit for peak LAI, which occurred at the transition between the vegetative and reproductive stages. The coefficient P5 was set to match the period of time between the simulated onset of linear grain growth and measured maturity date. The coefficient G3 was set to minimize error between simulated and measured tillers. Coefficients G1 and G2 were adjusted to minimize error between simulated and measured final yield. After calibration, the experimental data for Longjing 21 during 2011 to 2014, Longjing 31 during 2014 and 2015, and Kongyu 131 during 2011 were used for model evaluation. 
Table 1. Nine cultivar coefficients in CERES-Rice, calibrated for three cultivars.

\begin{tabular}{|c|c|c|c|c|}
\hline Cultivar Coefficient & Definition & Longjing 21 & Longjing 31 & Kongyu 131 \\
\hline P1 & $\begin{array}{l}\text { Time period expressed as growing degree days } \\
(G D D)^{1} \text { from emergence during which the plant } \\
\text { is not responsive to photoperiod }\end{array}$ & 209 & 161.5 & 184.5 \\
\hline $\mathrm{P} 2 \mathrm{O}$ & $\begin{array}{l}\text { Critical photoperiod at which the development } \\
\text { occurs at the maximum rate (hours) }\end{array}$ & 13 & 13 & 13 \\
\hline $\mathrm{P} 2 \mathrm{R}$ & $\begin{array}{l}\text { Extent to which phasic development leading to } \\
\text { panicle initiation is delayed for each hour } \\
\text { increase in photoperiod above P2O (GDD) }\end{array}$ & 5 & 5 & 5 \\
\hline P5 & $\begin{array}{l}\text { GDD from beginning of grain filling to } \\
\text { physiological maturity }\end{array}$ & 620 & 540 & 545 \\
\hline G1 & Potential spikelet number per g main culm & 90 & 86 & 90 \\
\hline G2 & $\begin{array}{l}\text { Single grain weight under ideal growing } \\
\text { conditions, mg }\end{array}$ & 0.027 & 0.027 & 0.027 \\
\hline G3 & $\begin{array}{l}\text { Tillering coefficient relative to IR64 cultivar } \\
\text { under ideal conditions }\end{array}$ & 0.9 & 0.9 & 1 \\
\hline G4 & Temperature tolerance coefficient. & 1 & 1 & 1 \\
\hline PHINT & Phyllochron interval, ${ }^{\circ} \mathrm{C}$ & 70 & 74 & 80 \\
\hline
\end{tabular}

\subsection{Weather Type Classification}

A total of 55 years of weather data (1960-2014) were available for long-term model analysis from a nearby weather station at Fujin, China. Weather years were statistically divided into three classes (cool, normal, and warm years) by summing up the accumulated growing degree days (GDD) from May 1st through to September 30th. This period was selected because the local rice gets transplanted in early May and harvested in late September. For perpetual years, May 1st has been a day of year 121 and September 30th has been a day of year 273. For leap years, May 1st and September 30th have been days of year 122 and 274, respectively. The GDD was calculated using Equation (1) given by Iwata [33] with a base temperature for rice of $10{ }^{\circ} \mathrm{C}$, as given by Gao et al. [34]. The accumulated $G D D_{1}$ was calculated each year in perpetual years using Equation (2), and the accumulated $G D D_{2}$ was calculated each year in leap years using Equation (3):

$$
\begin{gathered}
G D D=\frac{(T \max +T \min )}{2}-T_{\mathrm{b}} \\
\text { Accumulated } G D D_{1}=\sum_{i=121}^{n=273}(G D D) \\
\text { Accumulated } G D D_{2}=\sum_{i=122}^{n=274}(G D D)
\end{gathered}
$$

where $T_{\max }$ is the daily maximum temperature $\left({ }^{\circ} \mathrm{C}\right), T_{\min }$ is the daily minimum temperature $\left({ }^{\circ} \mathrm{C}\right)$, and $T_{\mathrm{b}}$ is the base temperature $\left({ }^{\circ} \mathrm{C}\right)$.

The Shapiro-Wilk and Kolmogorov-Smimov tests were used to determine whether the distribution of the cumulative GDD from May 1st to September 30th was normal. The significance analysis of 55 years of accumulated GDDs for the Shapiro-Wilk test was 0.6, and Kolmogorov-Smirnov test was 0.2. Both were larger than 0.05 and indicated that the distribution of the accumulated GDDs over 55 years of weather conformed to a normal distribution. Then, the 55 years of accumulated GDDs were divided into three weather categories based on a quartile statistical analysis. The 14 years with the lower $25 \%$ of accumulated GDDs were classified as cool weather years. The 26 years with the middle $50 \%$ of accumulated GDDs were classified as normal weather years. The 14 years with the upper $25 \%$ GDDs were classified as warm weather years. 


\subsection{Estimating Long-Term, Economically Optimum N Rates for Varieties and Different Weather Types}

The calibrated model was used to estimate the long-term economically optimum $\mathrm{N}$ rate (EONR) for each variety of rice under different types of weathers. The model was run for 21 different $\mathrm{N}$ rates ranging from 0 to $200 \mathrm{~kg} \mathrm{~N} \mathrm{ha}^{-1}$ in increments of $10 \mathrm{~kg} \mathrm{~N} \mathrm{ha}^{-1}$ for each season of weather data. Nitrogen applications were split into 40\% applied before transplanting, 30\% applied at tillering, and $30 \%$ applied at the stem elongation stage. This generated 1155 values of yield from each combination of year and $\mathrm{N}$ rate for each variety. The marginal net return (MNR) was computed for each $\mathrm{N}$ rate and year, following Equation (4):

$$
M N R=\text { Yield } \times \text { Price }- \text { Nrate } \times \text { Ncost }
$$

where Yield is the simulated rice yield with $\mathrm{N}$ applied, $\mathrm{kg} \mathrm{ha}^{-1}$; Price is the price for rice, assumed to be $\$ 0.43 \mathrm{~kg}^{-1}$; Nrate is the $\mathrm{N}$ application rate, $\mathrm{kg} \mathrm{ha}^{-1}$; and Ncost is the cost of $\mathrm{N}$, assumed to be $\$ 0.5 \mathrm{~kg}^{-1}$.

The EONR for a variety was defined as the $\mathrm{N}$ rate that maximized the MNR averaged over all weather years of a particular weather type (cool, normal, and warm), providing different estimates of EONR for each weather type.

\subsection{Evaluation of Different N Management Strategies}

In order to compare different strategies of $\mathrm{N}$ management responses to rice variety and weather type, we assumed the management of three hectares of fields from 1995 to 2014 (20 years), with one hectare each being planted with Longjing 21, Longjing 31, and Kongyu 131, respectively. During this period, 13 years belonged to the normal weather type, and 7 years belonged to the warm weather type. Note that none of the seasons from 1995-2014 was identified as a cool season based on the 55-season weather analysis. This was likely due to the impacts of climate change in the region. This first strategy consisted of running the model for 20 years using the current practice of $150 \mathrm{~kg} \mathrm{~N}$ $\mathrm{ha}^{-1}$ in this region, representing Farmer Practice (FP). The second strategy consisted of running the model over 20 years using the RONR of $120 \mathrm{~kg} \mathrm{~N}^{-1}$, representing regional optimal $\mathrm{N}$ management (RONM). In the third strategy, the average $\mathrm{N}$ rates for normal and warm weather types based on previous model simulation were used across rice varieties for the 13 normal weather years and 7 warm weather years, respectively, representing weather-specific N management (WSNM). In the fourth strategy, the average optimal $\mathrm{N}$ rates for the three different varieties were used across all weather types, respectively, representing variety-specific $\mathrm{N}$ management (VSNM). For the fifth strategy, the average variety- and weather type-specific $\mathrm{N}$ rates based on the previous simulation results were used for each variety and weather type of the 20 seasons, representing variety- and weather-specific $\mathrm{N}$ management (VWNM). The partial factor productivity (PFP) was calculated with rice yield divided by the amount of $\mathrm{N}$ applied.

\section{Results and Discussion}

\subsection{Model Calibration and Evaluation}

The CERES-Rice model performed well in both calibration and evaluation across rice varieties and $\mathrm{N}$ rates (Figure 1, Table 2) during the study period. Top weight and plant $\mathrm{N}$ uptake were simulated better either across varieties or for each variety than yield and LAI. Compared to the other three variables, the $R^{2}$ values for LAI were lower. The LAI calculations in the model are driven by coefficients embedded in the model code based on older varieties, and the user cannot easily change these values. It is likely that rice LAI in newer varieties is higher than what is programmed in CERES-Rice; thus, the model tended to underestimate the maximum LAI. The root mean square error $(R M S E)(\leq 0.90)$ and $R^{2}$ values $(\geq 0.70)$ for variety-specific LAI simulations were acceptable and comparable with other studies [35]. The model had the best performance for top weight $\left(R^{2} \geq 0.97\right.$, 
$R M S E \leq 1594)$, followed by plant $\mathrm{N}$ uptake $\left(R^{2} \geq 0.83, R M S E \leq 29\right)$ and yield $\left(R^{2} \geq 0.74, R M S E \leq 632\right)$. The CERES-Rice model performance in this study was consistent with that in warm climates [26]. This indicated that the model was able to simulate $\mathrm{N}$ yield responses well under a cool climate in the high-latitude area.
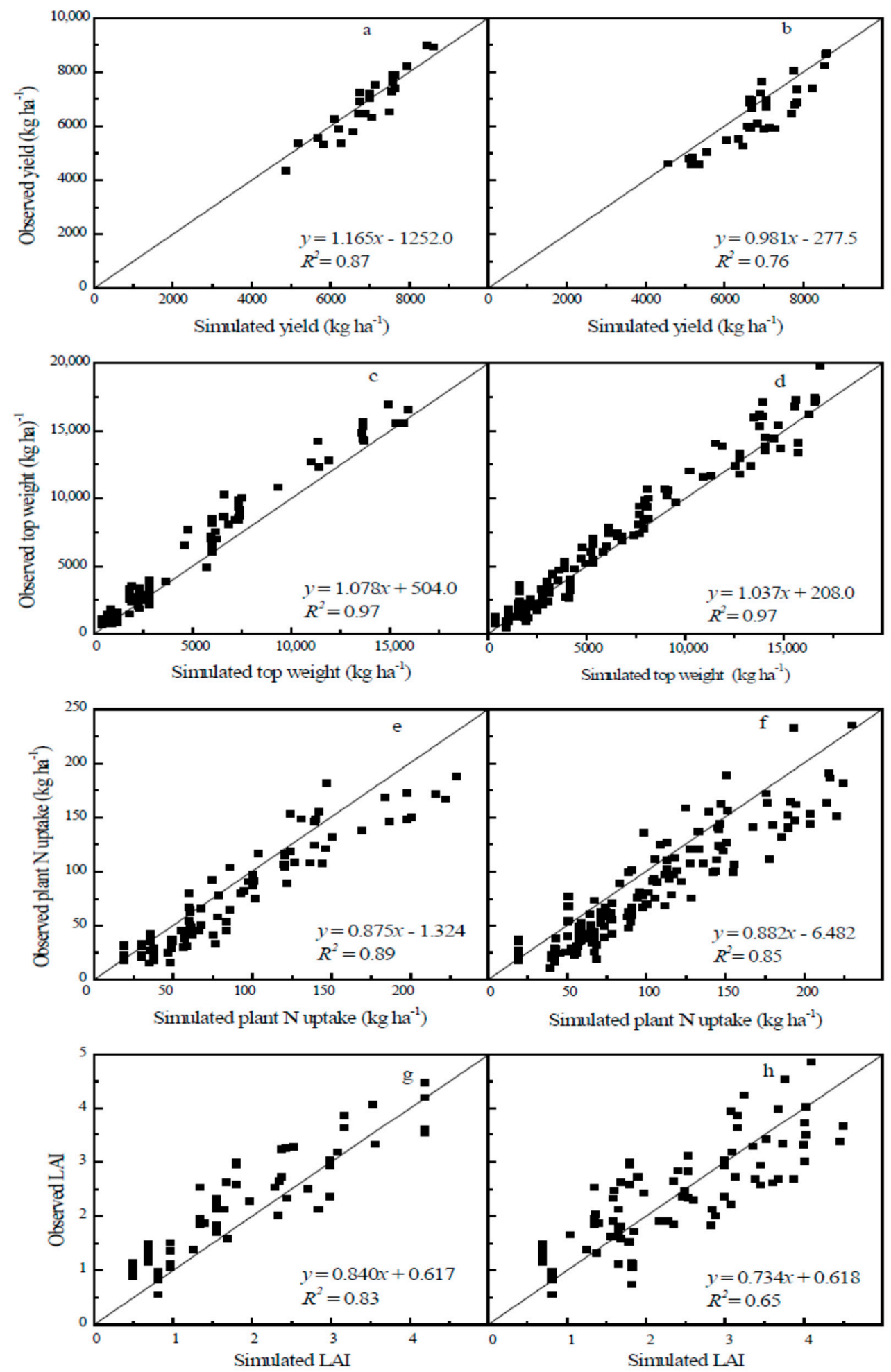

Figure 1. Calibration (left) and evaluation (right) results for simulated vs observed yield (a and b), top weight (c and $\mathbf{d}$ ), LAI (e and $\mathbf{f}$ ), and $\mathrm{N}$ uptake ( $\mathbf{g}$ and $\mathbf{h}$ ) over five $\mathrm{N}$ rates, three varieties, and several seasons. 
Table 2. Summary of CERES-Rice calibration and evaluation of three varieties, including four variables (yield, plant N uptake, top weight, LAI) with the experimental data during 2011-2016.

\begin{tabular}{|c|c|c|c|c|c|c|c|}
\hline \multirow{2}{*}{ Variety } & \multirow{2}{*}{ Parameter } & \multicolumn{3}{|c|}{ Calibration } & \multicolumn{3}{|c|}{ Evaluation } \\
\hline & & $R^{2}$ & Mean & RMSE & $R^{2}$ & Mean & RMSE \\
\hline \multirow[t]{4}{*}{ Longjing 21} & Yield $\left(\mathrm{kg} \mathrm{ha}^{-1}\right)$ & 0.71 & 6520 & 550 & 0.80 & 6197 & 758 \\
\hline & Plant $\mathrm{N}$ uptake $\left(\mathrm{kg} \mathrm{ha}^{-1}\right)$ & 0.91 & 72 & 22 & 0.83 & 85 & 29 \\
\hline & Top weight $\left(\mathrm{kg} \mathrm{ha}^{-1}\right)$ & 0.98 & 5507 & 993 & 0.96 & 7036 & 1094 \\
\hline & Leaf area index & 0.90 & 2.29 & 0.47 & 0.64 & 2.60 & 0.62 \\
\hline \multirow[t]{4}{*}{ Longjing 31} & Yield $\left(\mathrm{kg} \mathrm{ha}^{-1}\right)$ & 0.80 & 6370 & 306 & 0.74 & 6068 & 632 \\
\hline & Plant $\mathrm{N}$ uptake $\left(\mathrm{kg} \mathrm{ha}^{-1}\right)$ & 0.88 & 61 & 15 & 0.85 & 75 & 26 \\
\hline & Top weight $\left(\mathrm{kg} \mathrm{ha}^{-1}\right)$ & 0.97 & 4214 & 1594 & 0.97 & 5989 & 1158 \\
\hline & Leaf area index & 0.85 & 2.31 & 0.69 & 0.73 & 2.00 & 0.58 \\
\hline \multirow[t]{4}{*}{ Kongyu 131} & Yield $\left(\mathrm{kg} \mathrm{ha}^{-1}\right)$ & 0.95 & 7259 & 359 & 0.85 & 6283 & 403 \\
\hline & Plant $\mathrm{N}$ uptake $\left(\mathrm{kg} \mathrm{ha}^{-1}\right)$ & 0.88 & 86 & 23 & 0.92 & 70 & 27 \\
\hline & Top weight $\left(\mathrm{kg} \mathrm{ha}^{-1}\right)$ & 0.98 & 6287 & 1268 & 0.98 & 5275 & 672 \\
\hline & Leaf area index & 0.71 & 2.49 & 0.90 & 0.70 & 1.74 & 0.50 \\
\hline
\end{tabular}

\subsection{Simulating Economically Optimum N Rates and Yields of Three Varieties Under Three Weather Types}

The calibrated CERES-Rice model was used to simulate the $\mathrm{N}$ rate that maximized the MNR for each of the three varieties using 55 seasons of weather from 1960-2014 (Table 3). The average simulated EONR for Longjing 21 over the 55 years was $119 \mathrm{~kg} \mathrm{~N} \mathrm{ha}^{-1}$, which was higher than that of Longjing $31\left(100 \mathrm{~kg} \mathrm{~N} \mathrm{ha}^{-1}\right.$ ) and Kongyu $131\left(91 \mathrm{~kg} \mathrm{~N} \mathrm{ha}^{-1}\right.$ ) (Table 3). The minimum and maximum EONRs of Longjing 21 were also higher than the other two varieties, and had the least coefficient of variation $(C V, 18 \%)$ (Table 3). Longjing 21 (a 12-leaf variety) has a longer growing season than Longjing 31 and Kongyu 131, which are both 11-leaf varieties with a shorter growing season. The extra leaf and longer growing season of Longjing 21 resulted in higher biomass and yield potential, which required more $\mathrm{N}$ over the season to maximize MNR. Recent studies indicated that the optimum $\mathrm{N}$ application rate in this area was about $90-120 \mathrm{~kg} \mathrm{~N} \mathrm{ha}^{-1}$ [36]. Therefore, the results of this study are consistent with what others found in this region. Additionally, the EONRs varied significantly across the years for each variety (Table 3); for example, EONRs ranged from 50 to $170 \mathrm{~kg} \mathrm{~N} \mathrm{ha}^{-1}$ for Longjing 31. This was mainly caused by year-to-year weather variability and associated yield potential changes.

Table 3. Descriptive statistics of simulated, economically-optimum $\mathrm{N}$ rates that maximized marginal net return for the years of 1960-2014. Max. and Min. standard for maximum and minimum, respectively.

\begin{tabular}{|c|c|c|c|c|}
\hline \multirow{2}{*}{ Variety } & \multicolumn{4}{|c|}{ Economically Optimum N Rate } \\
\hline & $\operatorname{Mean}\left(\mathrm{kg} \mathrm{ha}^{-1}\right)$ & $\operatorname{Max} .\left(\mathrm{kg} \mathrm{ha}^{-1}\right)$ & Min. $\left(\mathrm{kg} \mathrm{ha}^{-1}\right)$ & $C V(\%)$ \\
\hline Longjing 21 & 119 & 180 & 80 & 18 \\
\hline Longjing 31 & 100 & 170 & 50 & 19 \\
\hline Kongyu 131 & 91 & 160 & 50 & 23 \\
\hline
\end{tabular}

Next, the model was used to determine the EONRs that maximized MNR for all three varieties for each of the three weather types (cool, normal, and warm). Results are summarized in Table 4. The average simulated EONR for the warm weather years was $115 \mathrm{~kg} \mathrm{~N} \mathrm{ha}^{-1}$, which was higher than the average EONR for the normal $\left(100 \mathrm{~kg} \mathrm{~N} \mathrm{ha}^{-1}\right)$ and cool $\left(99 \mathrm{~kg} \mathrm{~N} \mathrm{ha}^{-1}\right)$ weather years, which were nearly the same. Less variation in EONRs for cool weather years $(C V=20 \%)$ was observed. Warm weather extends the rice-growing period, and rice tends to consume more $\mathrm{N}$ and has a high NUE compared with the normal- and cool-weather years. A previous study reported that the high temperature or warm weather during the rice-growing season accelerated soil $\mathrm{N}$ mineralization and shortened the $\mathrm{N}$ release period [37]. These results suggested that if seasonal weather is warmer than normal, a farmer should increase the $\mathrm{N}$ rate to target a higher MNR. However, if the seasonal 
weather forecast indicates that a normal or cool season is likely, a farmer should follow a strategy of normal or lower $\mathrm{N}$ rates to obtain the highest possible MNR and reduce $\mathrm{N}$ loss in soil after harvest. The simulation results using the CERES-Rice model are in agreement with the understanding of a $\mathrm{N}$ cycle for rice.

Table 4. Summary of simulated, economically-optimum $\mathrm{N}$ rates that maximized marginal net return under three weather types across all varieties during 1960-2014.

\begin{tabular}{|c|c|c|c|c|}
\hline \multirow{2}{*}{ Weather Type } & \multicolumn{4}{|c|}{ Economically Optimum N Rate } \\
\hline & Mean $\left(\mathrm{kg} \mathrm{ha}^{-1}\right)$ & $\operatorname{Max} .\left(\mathrm{kg} \mathrm{ha}^{-1}\right)$ & Min. $\left(\mathrm{kg} \mathrm{ha}^{-1}\right)$ & $C V(\%)$ \\
\hline Cool & 99 & 160 & 50 & 20 \\
\hline Normal & 100 & 170 & 60 & 22 \\
\hline Warm & 115 & 180 & 70 & 24 \\
\hline
\end{tabular}

Furthermore, in order to explore the relationships between variety, $\mathrm{N}$ rate, and weather type, the EONRs of nine variety-weather combinations were simulated (Table 5). The variation of average EONRs ranged from 87 to $134 \mathrm{~kg} \mathrm{ha}^{-1}$. The Longjing 21-warm season combination had the highest EONR (134 kg ha $\left.{ }^{-1}\right)$, while the Longjing 31-cool and Kongyu 131-normal combinations had the lowest EONRs $\left(\leq 88 \mathrm{~kg} \mathrm{ha}^{-1}\right)$. Generally, the combinations with warm weather had higher EONRs than those with normal weather, and least for the cool weather seasons. The variety of Longjing 21 with one more leaf and a longer growing season had higher EONRs than the other two varieties under the same weather type.

Table 5. Summary of simulated, economically-optimum $\mathrm{N}$ rates that maximized marginal net return for nine variety-weather combinations during 1960-2014.

\begin{tabular}{|c|c|c|c|c|c|}
\hline \multirow{2}{*}{\multicolumn{2}{|c|}{ Variety Weather Type }} & \multicolumn{4}{|c|}{ Economically Optimum N Rate } \\
\hline & & Mean $\left(\mathrm{kg} \mathrm{ha}^{-1}\right)$ & $\operatorname{Max} .\left(\mathrm{kg} \mathrm{ha}^{-1}\right)$ & Min. $\left(\mathrm{kg} \mathrm{ha}^{-1}\right)$ & $C V(\%)$ \\
\hline \multirow{3}{*}{ Longjing 21} & Cool & 114 & 160 & 80 & 17 \\
\hline & Normal & 114 & 170 & 90 & 24 \\
\hline & Warm & 134 & 180 & 90 & 18 \\
\hline \multirow{3}{*}{ Longjing 31} & Cool & 94 & 110 & 50 & 18 \\
\hline & Normal & 98 & 150 & 70 & 19 \\
\hline & Warm & 111 & 170 & 70 & 23 \\
\hline \multirow{3}{*}{ Kongyu 131} & Cool & 88 & 100 & 50 & 16 \\
\hline & Normal & 87 & 150 & 60 & 23 \\
\hline & Warm & 101 & 160 & 70 & 26 \\
\hline
\end{tabular}

The simulated yield responses to $\mathrm{N}$ rates in a typical cool-, normal-, and warm-weather year for the three varieties are shown in Figure 2. Simulated yield in a warm year was consistently higher than a normal year, which had higher yield than a cool year. The same trend was observed for the EONRs under different weather conditions (Figure 2). The EONRs of the 12-leaf variety (Longing 21) were also shown to be relatively higher than the two 11-leaf varieties. The patterns of yield associated with $\mathrm{N}$ rates for varieties and types of weather seasons can be divided into two stages: the rapid increase of yield in response to $\mathrm{N}$, and the plateau stage where yield no longer responds to $\mathrm{N}$. Therefore, the simulated optimum $\mathrm{N}$ rates represented a common understanding of rice $\mathrm{N}$ uptake for different combinations of variety and types of weather years. 

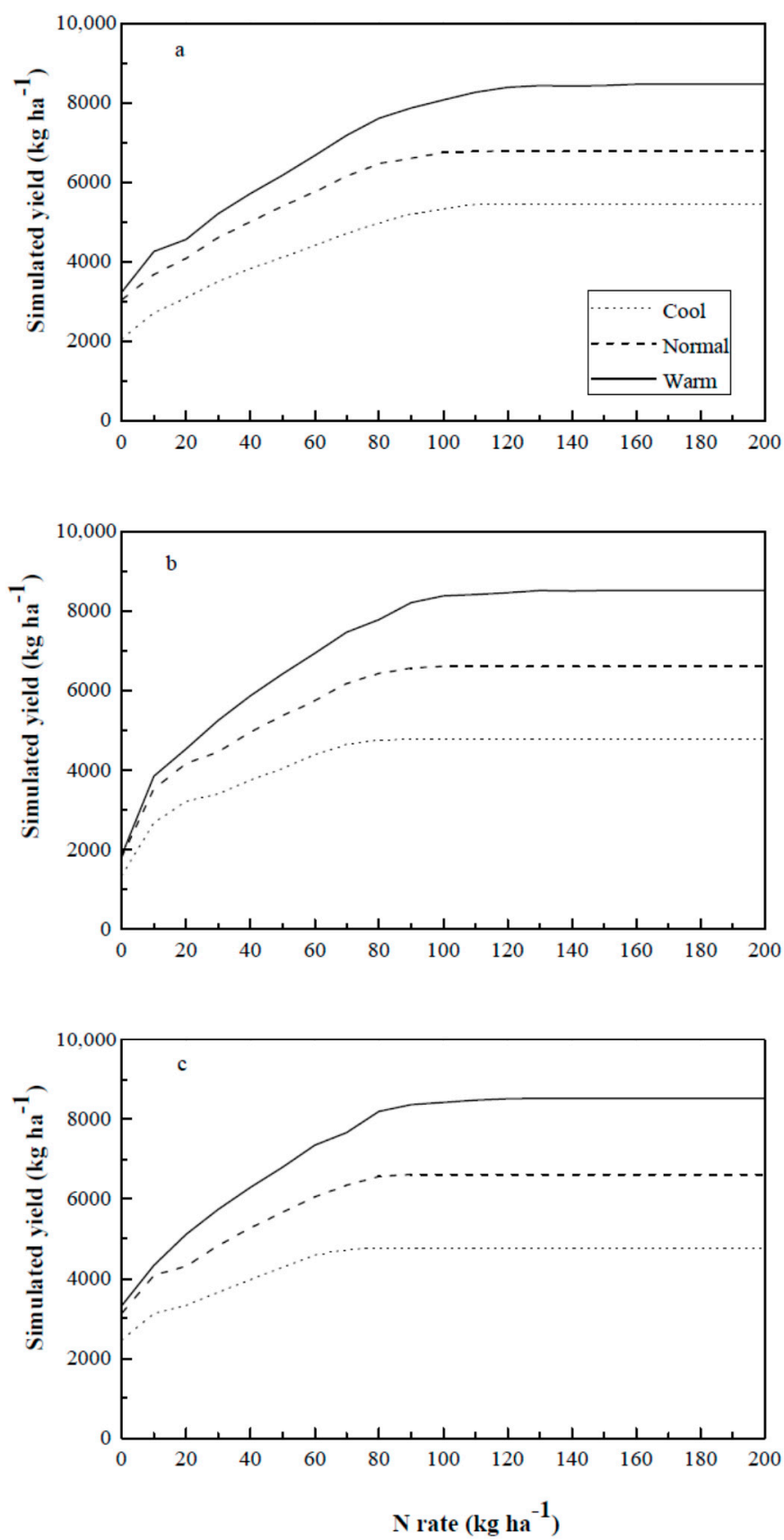

Figure 2. Rice-yield response to $\mathrm{N}$ rate for three rice varieties: (a) Longjing 21, (b) Longjing 31, and (c) Kongyu 131 in typical cool-, normal-, and warm-weather years.

\subsection{Evaluating Different N Management Strategies}

The simulated results of different $\mathrm{N}$ management strategies are shown in Table 6. Without consideration of weather-type effects (FP, RONM, and VSNM), the highest MNR ( $\$ 3097 \mathrm{ha}^{-1}$ ) was observed for Longjing 21 with $115 \mathrm{~kg} \mathrm{~N} \mathrm{ha}^{-1}$ in the VSNM strategy (Table 6). Although the yield (6931 kg ha ${ }^{-1}$ ) was slightly less than that of the Longjing 21 in FP, the MNR and NUE (PFP) was improved by about $\$ 160 \mathrm{ha}^{-1}$ and $10 \mathrm{~kg} \mathrm{~kg}^{-1}$, respectively. The NUE for three varieties in the VSNM strategy were apparently greater than those with FP and RONM. The highest PFP $\left(72 \mathrm{~kg} \mathrm{~kg}^{-1}\right)$ was observed for Kongyu 131 with a relatively low $\mathrm{N}$ rate $\left(91 \mathrm{~kg} \mathrm{ha}^{-1}\right)$. This suggested that the EONRs found using the CERES-Rice simulations could enhance the current farmer and regional $\mathrm{N}$ management for different varieties. 
Table 6. Simulated marginal net return (MNR), partial factor productivity (PFP), and yield under five management strategies based on different $\mathrm{N}$ rates, rice varieties, and weather types.

\begin{tabular}{|c|c|c|c|c|c|c|}
\hline Strategy & $\mathrm{N}$ rate $\left(\mathrm{kg} \mathrm{ha}^{-1}\right)$ & Variety & Weather Type & $\operatorname{MNR}\left(\$ \mathrm{ha}^{-1}\right)$ & $\operatorname{PFP}(\mathrm{N})\left(\mathrm{kg} \mathrm{kg}^{-1}\right)$ & Yield (kg ha $\left.{ }^{-1}\right)$ \\
\hline \multirow[t]{3}{*}{$\mathrm{FP}$} & 150 & Longjing 21 & & 2938 & 48.3 & 7238 \\
\hline & & Longjing 31 & & 2792 & 44.5 & 6668 \\
\hline & & Kongyu 131 & & 2791 & 44.4 & 6665 \\
\hline Average & & & & 2840 & 45.7 & 6857 \\
\hline \multirow[t]{3}{*}{ RONM } & 120 & Kongjing 21 & & 2920 & 57.8 & 6931 \\
\hline & & Longjing 31 & & 2800 & 55.4 & 6651 \\
\hline & & Longyu 131 & & 2794 & 55.3 & 6636 \\
\hline Average & & & & 2838 & 56.2 & 6739 \\
\hline \multirow[t]{6}{*}{ WSNM } & 100 & Longjing 21 & Normal & 2712 & 64.2 & 6424 \\
\hline & & Longjing 31 & Normal & 2634 & 62.4 & 6242 \\
\hline & & Kongyu 131 & Normal & 2624 & 62.2 & 6218 \\
\hline & 115 & Longjing 21 & Warm & 3225 & 66.4 & 7633 \\
\hline & & Longjing 31 & Warm & 3106 & 64.0 & 7358 \\
\hline & & Kongyu 131 & Warm & 3088 & 63.6 & 7316 \\
\hline Average & & & & 2826 & 63.5 & 6694 \\
\hline \multirow[t]{3}{*}{ VSNM } & 119 & Longjing 21 & & 3097 & 58.2 & 6931 \\
\hline & 100 & Longjing 31 & & 2770 & 65.5 & 6548 \\
\hline & 91 & Kongyu 131 & & 2769 & 72.0 & 6556 \\
\hline Average & & & & 2879 & 65.3 & 6678 \\
\hline \multirow[t]{6}{*}{ WVNM } & 114 & Longjing 21 & Normal & 2739 & 57.0 & 6502 \\
\hline & 134 & Longjing 21 & Warm & 3288 & 58.2 & 7801 \\
\hline & 98 & Longjing 31 & Normal & 2625 & 63.3 & 6206 \\
\hline & 111 & Longjing 31 & Warm & 3072 & 65.4 & 7262 \\
\hline & 87 & Kongyu 131 & Normal & 2622 & 71.4 & 6211 \\
\hline & 101 & Kongyu 131 & Warm & 3077 & 72.1 & 7285 \\
\hline Average & & & & 2831 & 64.4 & 6706 \\
\hline
\end{tabular}

Note: FP: farmer practice; RONM: regional optimum N management; WSNM: weather-specific N management; VSNM: variety-specific N management; WVNM: weather- and variety-specific $\mathrm{N}$ management.

The effects of $\mathrm{N}$ rate and weather type were integrated into the WSNM strategy. The MNR and yields of the warm weather years with $115 \mathrm{~kg} \mathrm{~N} \mathrm{ha}^{-1}$ were consistently greater than those of the normal weather years with $100 \mathrm{~kg} \mathrm{~N} \mathrm{ha}^{-1}$ for all three varieties in the WSNM strategy, but their PFP values were nearly the same. The effects of six combinations of $\mathrm{N}$ rate, variety, and weather year types were investigated in the WVNM strategy. Like WSNM, MNR, PFP, and the yields of three varieties favored the warm weather type. Higher PFP values and low N rates were observed for Kongyu 131.

The highest MNR ( $\left.\$ 3288 \mathrm{ha}^{-1}\right)$ and yield $\left(7801 \mathrm{~kg} \mathrm{ha}^{-1}\right)$ were found for Longjing 21, with $134 \mathrm{~kg}$ $\mathrm{N} \mathrm{ha}^{-1}$ for the warm-weather years in the WVNM strategy and a PFP of $58.2 \mathrm{~kg} \mathrm{~kg}^{-1}$, which is higher than all the combinations from different strategies. Therefore, the model analysis indicates that there is an opportunity to improve MNR and yield without reducing PFP. However, weather variability should be considered for the high-latitude region, and planting the 12-leaf variety could be risky in cooler weather.

\subsection{Implications for Rice N Management}

Variety selection is an important management decision, as demonstrated in this study. Due to climate warming, the average annual temperature in Heilongjiang has increased by about $2{ }^{\circ} \mathrm{C}$ from the 1960 s to 2000s [38]. Crop growth conditions have been greatly improved, with increased accumulated GDDs and an extended growth period [39], which is why the 12-leaf varieties have been introduced to Jiansanjiang in recent years. Such varieties were susceptible to failure due to low GDDs and cold weather in the past, but has now been able to mature safely in the Sanjiang Plain of Heilongjiang for most of the time in recent years. The results of this study indicated that the 12-leaf variety, Longjing 21, could produce higher yield than the commonly planted 11-leaf varieties (Kongyu 131 and Longing 31) in all the $\mathrm{N}$ management scenarios. Therefore, farmers are encouraged to select 12-leaf varieties in the Sanjiang Plain if the accumulated GDDs can meet the requirement of 12-leaf varieties. This is a crucial decision they can make in rice production, and is also an adaptation strategy to climate warming. 
After a variety is selected, determining the variety-specific optimal $\mathrm{N}$ rate is the next important consideration. The long-term optimal $\mathrm{N}$ rate for the 12-leaf variety, Longjing 21 , was higher than the 11-leaf varieties. This is because the longer growing-season variety has higher yield potential and requires more $\mathrm{N}$. Variety differences in $\mathrm{N}$ responses and optimal $\mathrm{N}$ rates have been previously reported by researchers for rice [40], maize [12,41], and so forth. The results of this study indicated that our particular strategy of adjusting $\mathrm{N}$ rates according to different varieties performed better than other strategies. The variety-specific EONR can be easily determined using crop growth models and long-term weather data, and farmers do not need to make any adjustments according to different weather types; therefore, it is a more practical $\mathrm{N}$ management strategy. A challenge is that varieties on the market are changing very fast, so it may not be easy to determine the suitable $\mathrm{N}$ rates for all varieties. The extension should work closely with breeding companies to get new data on different varieties and also provide variety-specific $\mathrm{N}$ rates when new varieties are introduced into their regions. A practical approach may be to classify major crop varieties into a few categories based on their responses to $\mathrm{N}$ fertilization, and determine the category-specific optimal $\mathrm{N}$ rates for all varieties to guide farmers in crop management.

Another consideration could be the possible type of weather condition for the upcoming growing season. Meteorologists can often forecast whether the seasonal weather will be warmer or cooler than normal. Under warm weather conditions, rice yield is higher than under normal weather conditions, and therefore requires higher $\mathrm{N}$ fertilizer rates. The long-term optimal $\mathrm{N}$ rates were similar for cool and normal weather conditions in this study. The challenge of adjusting $\mathrm{N}$ management according to different weather conditions is that the weather type of the coming season is not reliably forecasted at planting time. Since rice farmers generally apply $\mathrm{N}$ fertilizers in 3-4 splits in this region, the topdressing $\mathrm{N}$ rates can be adjusted according to the specific weather conditions of the current growing season. Remote and proximal sensing technologies are commonly used for diagnosing rice $\mathrm{N}$ status and guiding in-season $\mathrm{N}$ management [13,14,42]. The results of the study indicated that WSNM and WVNM did not improve MNR and NUE compared with VSNM. A possible reason is that the current classification of three weather year types may not be enough, and there is still significant year-to-year variability in weather conditions and EONRs within the same weather year type (Tables 4 and 5).

It should be noted that even NUE can be increased using the different $\mathrm{N}$ management strategies evaluated in this study, whereas grain yield is generally lower than farmer practice. Thus, farmers would not be convinced to change their $\mathrm{N}$ management practices, meaning that it is necessary to integrate precision $\mathrm{N}$ management strategies with other high-yield management practices to increase both yield and NUE simultaneously to make it attractive to farmers. For example, Zhao et al. [4] combined chlorophyll meter-based precision $\mathrm{N}$ management with optimized planting density and alternate wetting and drying irrigation to increase yield by $10 \%$ and NUE by $97 \%$ at the same time.

In summary, variety-specific $\mathrm{N}$ management demonstrated in this study has the potential to significantly increase NUE compared with either farmer practice or regional optimum $\mathrm{N}$ management strategies. The CERES-Rice crop growth model can be a useful tool to help determine the varietyand weather-specific $\mathrm{N}$ rates based on long-term simulation analysis. Further studies are needed to improve the classification of weather year types, develop methods to predict weather year types using in-season weather data before planting and topdressing $\mathrm{N}$ applications, and validate such model-assisted variety- and weather-specific $\mathrm{N}$ management strategies under on-farm conditions.

\section{Conclusions}

The CERES-Rice model gave good simulations of rice top weight, plant $\mathrm{N}$ uptake, yield, and LAI for a high-latitude cool climate. The simulated optimum $\mathrm{N}$ rates of three rice varieties under different weather types were in the range of local and regional optimum $\mathrm{N}$ rates reported by recent studies. Through the comparison of five different $\mathrm{N}$ management strategies, both varieties and weather types contributed to the variation of MNR and PFP under different optimal N rates. Due to global warming, selection of the 12-leaf variety, Longjing 21, is likely to produce a higher crop yield and MNR than 
the 11-leaf varieties under all the management strategies evaluated. The longer growing season for the high-yielding, 12-leaf variety would require higher $\mathrm{N}$ rates than 11-leaf varieties. In general, under warm weather conditions, all the rice varieties would produce higher yield, and thus require higher rates of $\mathrm{N}$ fertilizers. The model simulations indicated that variety-specific $\mathrm{N}$ management was a practical $\mathrm{N}$ management strategy that would improve MNR and NUE over FP and RONM. The CERES-Rice crop growth model can be used as a useful tool to provide farmers with multiple alternatives of precision $\mathrm{N}$ management based on weather forecast and variety selection.

Author Contributions: Y.M. and W.B. conceived the study. J.L., H.W. and J.Z. conducted part of field experiments, and J.Z. and W.B performed the model analysis. J.Z. wrote the original manuscript. Y.M., W.B. and S.K. reviewed and revised the manuscript. All authors read and approved the final manuscript.

Funding: This research was financially supported by the National Key Research and Development Program of China (2016 YFD0200600, 2016YFD0200602), the National Basic Research Program (2015CB150405), Norwegian Ministry of Foreign Affairs (SINOGRAIN I \& II, CHN-17/0019) and the National Institute of Food and Agriculture, U.S. Department of Agriculture, Hatch project (ALA014-1-16016).

Acknowledgments: We would like to thank Qiang Cao, Weifeng Yu, Jianning Shen, Jingxin Li., Wei Shi, Shanyu Huang, Martin Gnyp, Xiaoyi Hu, Jun Wan, Xiao Gao, Weichao Sun, Zhengqi Feng, Shanshan Hu, Shanshan Cheng, Linlin Xin, Rui Huang, and Haibin Wu for their contributions to the field experiments and data collection. We also would like to express appreciation to assistance provided by Guojun Li, Wen Yang, Yuan Gao, Fengyan Liu, Huamin $\mathrm{Zhu}$, and Honglin Li and Xiaolong Wang.

Conflicts of Interest: The authors declare no conflict of interest.

\section{References}

1. Seck, P.A.; Diagne, A.; Mohanty, S.; Wopereis, M.C.S. Crops that feed the world 7: Rice. Food Secur. 2012, 4, 7-24. [CrossRef]

2. Peng, S.; Buresh, R.J.; Huang, J.; Zhong, X.; Zou, Y.; Yang, J.; Wang, G.; Liu, Y.; Hu, R.; Tang, Q.; et al. Improving nitrogen fertilization in rice by site-specific $\mathrm{N}$ management-A review. Agron. Sustain. Dev. 2010, 30, 649-656. [CrossRef]

3. Pan, G.X.; Li, L.Q.; Wu, L.S.; Zhang, X.H. Storage and sequestration potential of topsoil organic carbon in China's paddy soils. Glob. Chang. Biol. 2003, 10, 79-92. [CrossRef]

4. Zhao, G.; Miao, Y.; Wang, H.; Su, M.; Fan, M.; Zhang, F.; Jiang, R.; Zhang, Z.; Liu, C.; Liu, P. A preliminary precision rice management system for increasing both grain yield and nitrogen use efficiency. Field Crops Res. 2013, 154, 23-30. [CrossRef]

5. Su, M.; Huang, S.; Zhao, G.; Zhao, Q.; Yao, Y.; Miao, Y. Current rice management practices of farmers in Heilongjiang land reclamation area and improvement strategies. North. Rice 2012, 42, 28-33, (In Chinese with English Abstract).

6. Cao, Q.; Miao, Y.; Wang, H.; Huang, S.; Cheng, S.; Khosla, R.; Jiang, R. Non-destructive estimation of rice plant nitrogen status with Crop Circle multispectral active canopy sensor. Field Crops Res. 2013, 154, 133-144. [CrossRef]

7. Cui, Z.; Chen, X.; Zhang, F. Development of regional nitrogen rate guidelines for intensive cropping systems in China. Agron. J. 2013, 105, 1411-1416. [CrossRef]

8. Wu, L.; Chen, X.; Cui, Z.; Wang, G.; Zhang, W. Improving nitrogen management via a regional management plan for Chinese rice production. Environ. Res. Lett. 2015, 10. [CrossRef]

9. Cao, Q.; Miao, Y.; Feng, G.; Gao, X.; Liu, B.; Liu, Y.; Li, F.; Khosla, R.; Mulla, D.J.; Zhang, F. Improving nitrogen use efficiency with minimal environmental risks using an active canopy sensor in a wheat-maize cropping system. Field Crops Res. 2017, 214, 365-372. [CrossRef]

10. Flowers, M.; Weisz, R.; Heiniger, R.; Osmond, D.; Crozier, C. In-season optimization and site-specific nitrogen management for soft red winter wheat. Agron. J. 2004, 96, 124-134. [CrossRef]

11. Miao, Y.; Mulla, D.J.; Batchelor, W.D.; Paz, J.O.; Robert, P.C. Evaluating management zone optimal N rates with a crop growth model. Agron. J. 2006, 98, 545-553. [CrossRef]

12. Miao, Y.; Mulla, D.J.; Hernandez, J.A.; Wiebers, M.; Robert, P.C. Potential impact of precision nitrogen management on corn yield, protein content, and test weight. Soil Sci. Soc. Am. J. 2007, 71, 1490-1499. [CrossRef] 
13. Huang, S.; Miao, Y.; Zhao, G.; Yuan, F.; Ma, X.; Tan, C.; Yu, W.; Gnyp, M.L.; Lenz-Wierdemann, V.I.S.; Rascher, U.; et al. Satellite remote sensing-based in-season diagnosis of rice nitrogen status in Northeast China. Remote Sens. 2015, 7, 10646-10667. [CrossRef]

14. Lu, J.; Miao, Y.; Shi, W.; Li, J.; Yuan, F. Evaluating different approaches to non-destructive nitrogen status diagnosis of rice using portable RapidSCAN active canopy sensor. Sci. Rep. 2017, 7. [CrossRef] [PubMed]

15. Mulla, D.J.; Miao, Y. Precision Farming. In Land Resources Monitoring, Modeling, and Mapping with Remote Sensing; Thenkabail, P.S., Ed.; CRC Press: Boca Raton, FL, USA, 2016.

16. Batchelor, W.D.; Basso, B.; Paz, J.O. Examples of strategies to analyze spatial and temporal yield variability using crop models. Eur. J. Agron. 2002, 18, 141-158. [CrossRef]

17. Thorp, K.R.; Batchelor, W.D.; Paz, J.O.; Steward, B.L.; Caragea, P.C. Methodology to link production and environmental risks of precision nitrogen management strategies in corn. Agric. Syst. 2006, 89, 272-298. [CrossRef]

18. Sala, S.; van Es, H.M.; Moebius-Clune, B.N.; Marjerison, R.; Moeblus-Clune, D.; Schindelbeck, R.; Severson, K.; Young, E. Dynamic model improves agronomic and environmental outcomes for maize nitrogen management over static approach. J. Environ. Qual. 2017, 46, 311-319. [CrossRef] [PubMed]

19. Hoogenboom, G.; Jones, J.W.; Porter, C.H.; Wilkens, P.W.; Boote, K.J.; Hunt, L.A.; Tsuji, G.Y. Decision Support System for Agrotechnology Transfer Version 4.5; Volume 1: Overview; University of Hawaii: Honolulu, HI, USA, 2010.

20. Link, E.J.; Graeff, S.S.; Batchelor, W.D.; Claupein, W. Evaluating the economic and environmental impact of a German compensation payment policy under uniform and variable-rate nitrogen management strategies using a crop model. Agric. Syst. 2006, 91, 135-153. [CrossRef]

21. Link, E.J.; Graeff, S.; Batchelor, W.D. Evaluation of current and model-based site-specific nitrogen applications on wheat (Triticum aestivum L.) yield and environmental quality. Precis. Agric. 2008, 9, 251-267. [CrossRef]

22. Paz, J.O.; Batchelor, W.D.; Colvin, T.S.; Logsdon, S.D.; Kaspar, T.C.; Karlen, D.L.; Babcock, B.A.; Pautsch, G.R. Model-based techniques to determine variable rate nitrogen for corn. Agric. Syst. 1999, 60, 69-75. [CrossRef]

23. Paz, J.O.; Batchelor, W.D.; Jones, J.W. Estimating potential economic return for variable rate soybean variety management. Trans. ASAE 2003, 46, 1225-1234.

24. Cheyglinted, S.; Ranamukhaarachchi, S.L.; Singh, G. Assessment of the CERES-Rice model for rice production in the central plain of Thailand. J. Agric. Sci. 2001, 137, 289-298. [CrossRef]

25. Singh, H.; Singh, K.N.; Hasan, B. Evaluation of CERES-Rice model (V. 4.0) under temperate conditions of Kashmir Valley, India. Cereal Res. Commun. 2007, 35, 1723-1732. [CrossRef]

26. Vilayvong, S.; Banterng, P.; Patanothai, A.; Pannangpetch, K. Evaluation of CSM-CERES-Rice in simulating the response of lowland rice cultivars to nitrogen application. Aust. J. Crop Sci. 2012, 6, 1534-1541.

27. Yao, F.; Xu, Y.; Feng, Q.; Lin, E.; Yan, X. Simulation and validation of CERES-rice model in main rice ecological zones in China. Acta Agron. Sin. 2015, 31, 545-550.

28. Ahmad, S.; Ahmad, A.; Tojo Soler, C.M.; Ali, H.; Zia-Ul-Haq, M.; Anothai, J.; Hussain, A.; Hoogenboom, G.; Hasanuzzaman, M. Application of the CSM-CERES-Rice model for evaluation of plant density and nitrogen management of fine transplanted rice for an irrigated semiarid environment. Precis. Agric. 2012, 13, 200-218. [CrossRef]

29. Gerardeaux, E.; Giner, M.; Ramanantsoanirina, A.; Dusserre, J. Positive effects of climate change on rice in Madagascar. Agron. Sustain. Dev. 2012, 32, 619-627. [CrossRef]

30. Yan, M.; Deng, W.; Chen, P. Climate change in the Sanjiang Plain disturbed by large-scale reclamation. J. Geogr. Sci. 2002, 12, 405-412.

31. Zhou, Z.; Liu, T. The current status, threats and protection way of Sanjiang Plain wetland, northeast China. J. For. Res. 2005, 16, 148-152.

32. Bo, J.H.; Wang, K.R.; Chu, Z.D.; Chen, B.; Li, S.K. Comparative study on the measure methods of the leaf area. J. Shihezi Univ. 2005, 23, 216-218.

33. Iwata, F. Heat Unit Concept of Crop Maturity, Physiological Aspects of Dry Land Farming; Gupta, U.S., Ed.; Oxford and IBH Publishers: New Delhi, India, 1984; pp. 351-370.

34. Gao, L.; Jin, Z.; Huang, Y.; Zhang, L. Rice clock model: A computer model into simulate rice development. Agric. For. Meteorol. 1992, 60, 1-16. [CrossRef]

35. Basso, B.; Liu, L.; Ritchie, J.T. A Comprehensive Review of the CERES-Wheat, -Maize and -Rice Models' Performances. Adv. Agron. 2016, 136, 27-132. 
36. Zhang, F.S.; Chen, X.P.; Chen, Q. Guidelines for Fertilization in Northeast China. Guide to Fertilization for Major Crops in China; China Agricultural University Press: Beijing, China, 2009; pp. 48-53.

37. Wang, X.; Xu, S. Experimental study on the effect of climate warming on soil fertilizer and fertilizer efficiency. Meteorology 1996, 22, 12-16, (In Chinese with English Abtract).

38. Gao, J.; Liu, Y. Climate warming and land use change in Heilongjiang Province, Northeast China. Appl. Geogr. 2011, 31, 476-482. [CrossRef]

39. Yang, X.; Lin, E.; Ma, S.; Ju, H.; Guo, L.; Xiong, W.; Li, Y.; Xu, Y. Adaptation of agriculture to warming in Northeast China. Clim. Chang. 2007, 84, 45-58. [CrossRef]

40. Saleque, M.A.; Naher, U.A.; Choudhury, N.N.; Hossain, A.T.M.S. Variety-specific nitrogen fertilizer recommendation for lowland rice. Commun. Soil Sci. Plant Anal. 2005, 35, 1891-1903. [CrossRef]

41. Miao, Y.; Mulla, D.J.; Robert, P.C.; Hernandez, J.A. Within-field variation in corn yield and grain quality responses to nitrogen fertilization and hybrid selection. Agron. J. 2006, 98, 129-140. [CrossRef]

42. Yao, Y.; Miao, Y.; Huang, S.; Gao, L.; Ma, X.; Zhao, G.; Jiang, R.; Chen, X.; Zhang, F.; Yu, K.; et al. Active canopy sensor-based precision N management strategy for rice. Agron. Sustain. Dev. 2012, 32, 925-933. [CrossRef]

(C) 2018 by the authors. Licensee MDPI, Basel, Switzerland. This article is an open access article distributed under the terms and conditions of the Creative Commons Attribution (CC BY) license (http://creativecommons.org/licenses/by/4.0/). 